\title{
Characterization of an alkaline esterase from an enriched metagenomic library derived from an oil-spill area
}

\author{
Seung Cheol Baek ${ }^{1} \cdot$ Jeong Min Jo ${ }^{2} \cdot$ Soo-Mi Jeong ${ }^{2} \cdot$ Jae Pil Lee ${ }^{1}$. \\ Hyun Woo Lee ${ }^{1} \cdot$ Jungho Kim ${ }^{2} \cdot$ Hoon Kim ${ }^{1,2}$ iD
}

Received: 13 December 2018 / Accepted: 15 January 2019 / Published Online: 31 March 2019

(C) The Korean Society for Applied Biological Chemistry 2019

\begin{abstract}
A novel esterase gene (est $7 \mathrm{~S})$ was cloned from an enriched metagenomic library derived from an oil-spill area. The gene encoded a protein of 505 amino acids, and the molecular mass of the Est7S was estimated to be 54,512 Da with no signal peptide. Est7S showed the highest identity of $40 \%$ to an esterase from a sludge metagenome compared to the characterized enzymes with their properties, although it showed $99 \%$ identity to a carboxylesterase in the genome sequence of Alcanivorax borkumensis SK2. Est7S had catalytic triad residues, Ser183, Glu312, and His420, and the GESAG motif in most family VII lipolytic enzymes. Est7S was purified from the crude extract of clone SM7 using Sephacryl S-200 HR and HiTrap Q column chromatographies. The purified Est7S was optimally active at $50{ }^{\circ} \mathrm{C}$ and $\mathrm{pH} 10.0$. Est7S showed a high specific activity of $366.7 \mathrm{U} / \mathrm{mg}$ protein. It preferred short length esters, particularly $p$-nitrophenyl acetate, efficiently hydrolyzed $R$ - and $S$-enantiomers of methyl-3-hydroxy2-methylpropionate, and glyceryl tributyrate. These properties of Est7S may provide potential merits in biotechnological applications such as detergent and paper processing under alkaline conditions.
\end{abstract}

Keywords Alkaline family VII esterase $\cdot$ Enriched metagenomic library $\cdot$ Purification $\cdot$ Short length $p$-nitrophenyl esters

Hoon $\operatorname{Kim}(\triangle)$

E-mail: hoon@sunchon.ac.kr

${ }^{1}$ Department of Pharmacy, and Research Institute of Life Pharmaceutical Sciences, Sunchon National University, Suncheon 57922, Republic of Korea

${ }^{2}$ Department of Agricultural Chemistry, Sunchon National University, Suncheon 57922, Republic of Korea

This is an Open Access article distributed under the terms of the Creative Commons Attribution Non-Commercial License (http://creativecommons. org/licenses/by-nc/3.0/) which permits unrestricted non-commercial use, distribution, and reproduction in any medium, provided the original work is properly cited.

\section{Introduction}

Esterases (EC 3.1.1.1) and lipases (EC 3.1.1.3) are generally categorized based on the chain length preference of fatty acid esters to be hydrolyzed. Esterases and lipases have been used in a variety of biological applications for degradation processes, such as detergent, food, animal feed, textile, and pulping, as well as for synthesis of pharmaceuticals, agrochemicals, biopolymers, and flavor compounds [1,2]. Recently, the lipolytic enzymes have been attracted as fused forms for the improvement of their thermostability, catalytic activity, substrate specificity, and regioor enantio-selectivity, and also for facilitation of their purification and yield [3].

Bacterial lipolytic enzymes were originally classified into eight families based their sequences and biological properties [4], and expanded to fifteen families [5]. Besides microorganisms, biocatalysts have been explored using a metagenomic approach without culturing of microorganisms, due to the limitation of culture [6]. Marine microorganisms can serve as an untapped source of industrial biocatalysts, which are different from terrestrial microorganisms. We isolated two novel strains from an oil-contaminated seashore to degrade the contaminants $[7,8]$. We also have previously reported two novel enzymes, a family IV esterase and a family I.3 lipase, from an oil-polluted mud flat metagenome [9]. When the sample was enriched with specific substrates, microbial diversity could hugely increase.

In this study, we isolated a novel alkaline family VII esterase gene (est $7 \mathrm{~S}$ ) with high specific activity from a metagenomic library derived from an enriched marine sediments contaminated with crude oil, and examined enzymatic properties of Est7S.

\section{Materials and Methods}

\section{Materials}

Substrates, such as $p$-nitrophenyl esters, enantiomers $[(R)-$ and 
(S)-methyl-3-hydroxy-2-methylpropionate], glyceryl esters (glyceryl tributyrate and glyceryl trioctanoate), and oils (fish oil and olive oil), along with other chemicals, were purchased from Sigma (St. Louis, MO, USA). The compounds 5-Bromo-4-chloro-3-indolyl$\beta$-D-galactoside (X-gal) and isopropylthio- $\beta$-D-galactoside (IPTG) were obtained from Bioneer (Daejeon, Korea). Sephacryl S-200 HR and HiTrap Q HP columns were from GE Healthcare (Uppsala, Sweden).

\section{Selection of esterase-positive clones from enriched and mixed culture}

Oil-spilled fine gravels and sands were sampled, as described previously [9]. The sample was enriched by adding $0.5 \%$ crude oil into $\mathrm{BM}$ medium [2\% sea salt, $10 \mathrm{mM}$ phosphate buffer, $0.25 \mathrm{~g}$ $\mathrm{MgSO}_{4} \cdot 7 \mathrm{H}_{2} \mathrm{O}, 0.02 \mathrm{~g} \mathrm{CaCl}_{2} \cdot 2 \mathrm{H}_{2} \mathrm{O}, 0.02 \mathrm{~g} \mathrm{FeSO}_{4} \cdot 7 \mathrm{H}_{2} \mathrm{O}, 2.38 \mathrm{~g}$ $\left(\mathrm{NH}_{4}\right)_{2} \mathrm{SO}_{4}$ per $\left.\mathrm{L}\right]$ and grown three times at $25^{\circ} \mathrm{C}$ for 10 days. Enriched metagenome was then extracted and partially digested with Sau3AI by the method previously described [10]. After the digested $3-8 \mathrm{~kb}$ fragments were inserted into pUC19 vector, transformants were grown on LB agar plates supplemented by Xgal and IPTG, and then positive clones were selected by using LB plates that contained $1 \%$ glyceryl tributyrate [11]. Recombinant plasmids of the clones were analyzed.

\section{Sequence analysis of the gene}

The nucleotide sequence of the insert DNA was determined by SolGent (Daejeon, Korea). The conserved regions were detected using BLAST at the NCBI (http://www.ncbi.nlm. nih.gov). Putative signal peptide was predicted by SignalP 4.1 in CBS (http:// www.cbs. dtu.dk/services/SignalP/) [12]. The molecular mass estimation and multiple alignment were analyzed using DNA/ MAN (Lynnon Biosoft, version 4.11, Quebec, Canada).

\section{Esterase assay}

Esterase activity was assayed by measuring the amount of $p$ nitrophenol generated from $p$-nitrophenyl butyrate $(p N P B)$, as described previously [10]. Under the standard conditions, the reaction was carried out for $2 \mathrm{~min}$ at $25^{\circ} \mathrm{C}$ in the presence of $1 \mathrm{mM} p \mathrm{NPB}$ in $50 \mathrm{mM}$ Tris $/ \mathrm{HCl}(\mathrm{pH} 8.0)$ and continuously measured at $400 \mathrm{~nm}$ using a spectrophotometer (Mecasys, Model OPTIZEN, Korea). Enzyme activities were calculated using molar-extinction coefficients for $p$-nitrophenol $(16,520 / \mathrm{M} / \mathrm{cm}$ at $\mathrm{pH}$ 8.0) [10]. One unit of esterase activity was defined as the amount of enzyme that generated $1 \mu \mathrm{mol}$ of $p$-nitrophenol in 1 min under the condition.

\section{Purification of the enzyme}

Crude enzyme preparation was performed as previously described [13]. The crude enzyme was loaded onto a Sephacryl S-200 HR column (HiPrep 16/60) after dialysis against $50 \mathrm{mM}$ sodium phosphate buffer ( $\mathrm{pH}$ 7.2) containing $150 \mathrm{mM} \mathrm{NaCl}$ [14]. The protein was eluted at a flow rate of $0.5 \mathrm{~mL} / \mathrm{min}$. The enzyme was purified by HiTrap Q HP (5 mL) column chromatography. Protein concentration was determined using the Bradford method [15] and SDS-PAGE on an $11.5 \%$ polyacrylamide gel [16].

\section{Characterization of the enzyme}

Optimum temperature, thermostability, optimum $\mathrm{pH}$, cation effect, and substrate specificity of the enzyme were determined, as described previously [10]. Hydrolyzing activities for $p$-nitrophenol derivatives were analyzed using the following $p$-nitrophenyl esters: $p$ nitrophenyl acetate $(\mathrm{C} 2), p$-nitrophenyl butyrate $(\mathrm{C} 4)$, octanoate $p$ nitrophenyl octanoate (C8), $p$-nitrophenyl caprate (C10), $p$ nitrophenyl laurate $(\mathrm{C} 12), p$-nitrophenyl myristate $(\mathrm{C} 14)$, and $p$ nitrophenyl palmitate (C16). Enantioselectivity was analyzed using $300 \mathrm{mM}(R)$ - or $(S)$-methyl-3-hydroxy-2-methylpropionate in $20 \mathrm{mM}$ Tris $/ \mathrm{HCl},(\mathrm{pH} 8.0)$ containing phenol red $(0.01 \mathrm{~g} / \mathrm{L})$ with modifications [11]. The reaction mixtures $(0.6 \mathrm{~mL})$ containing $2.0 \mathrm{U} / \mathrm{mL}$ of Est7S were reacted for $1 \mathrm{~h}$ at $25^{\circ} \mathrm{C}$ and the absorbance spectra were recorded at $560 \mathrm{~nm}$. Hydrolysis of glyceryl esters, such as glyceryl butyrate and glyceryl trioleate, and oils, such as fish and olive oil, were analyzed using $1 \%$ substrates.

\section{Nucleotide sequence accession number}

The nucleotide sequence of the esterase gene est $7 \mathrm{~S}$ has been deposited in the GenBank under accession number MK290416.

\section{Results and Discussion}

\section{Characterization of an esterase gene est $7 \mathrm{~S}$ and Est7S}

Among 1,500 transformants, eight clones were screened as positive clones and confirmed on an LB plate containing $1 \%$ glyceryl tributyrate as a substrate (Fig. 1). After analyzing the plasmids by four restriction enzymes such as EcoRI, BamHI, HindIII, and PstI, and comparing esterase activities on the plate, clone SM7 was selected for further study. The size of the insert fragment of SM7 was about $3.0 \mathrm{~kb}$, containing an open reading

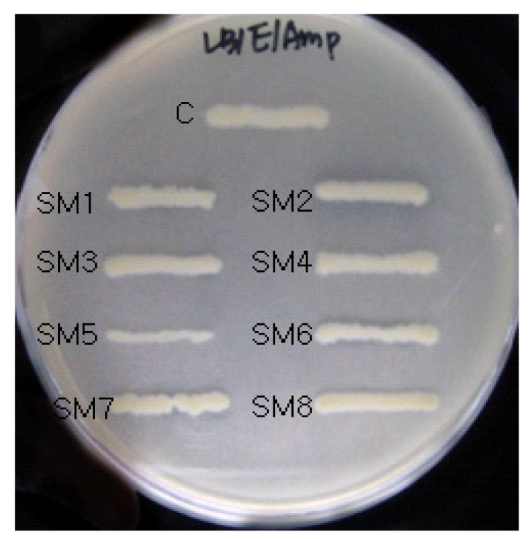

Fig. 1 Detection of esterase-positive clones. C, control 
(A)

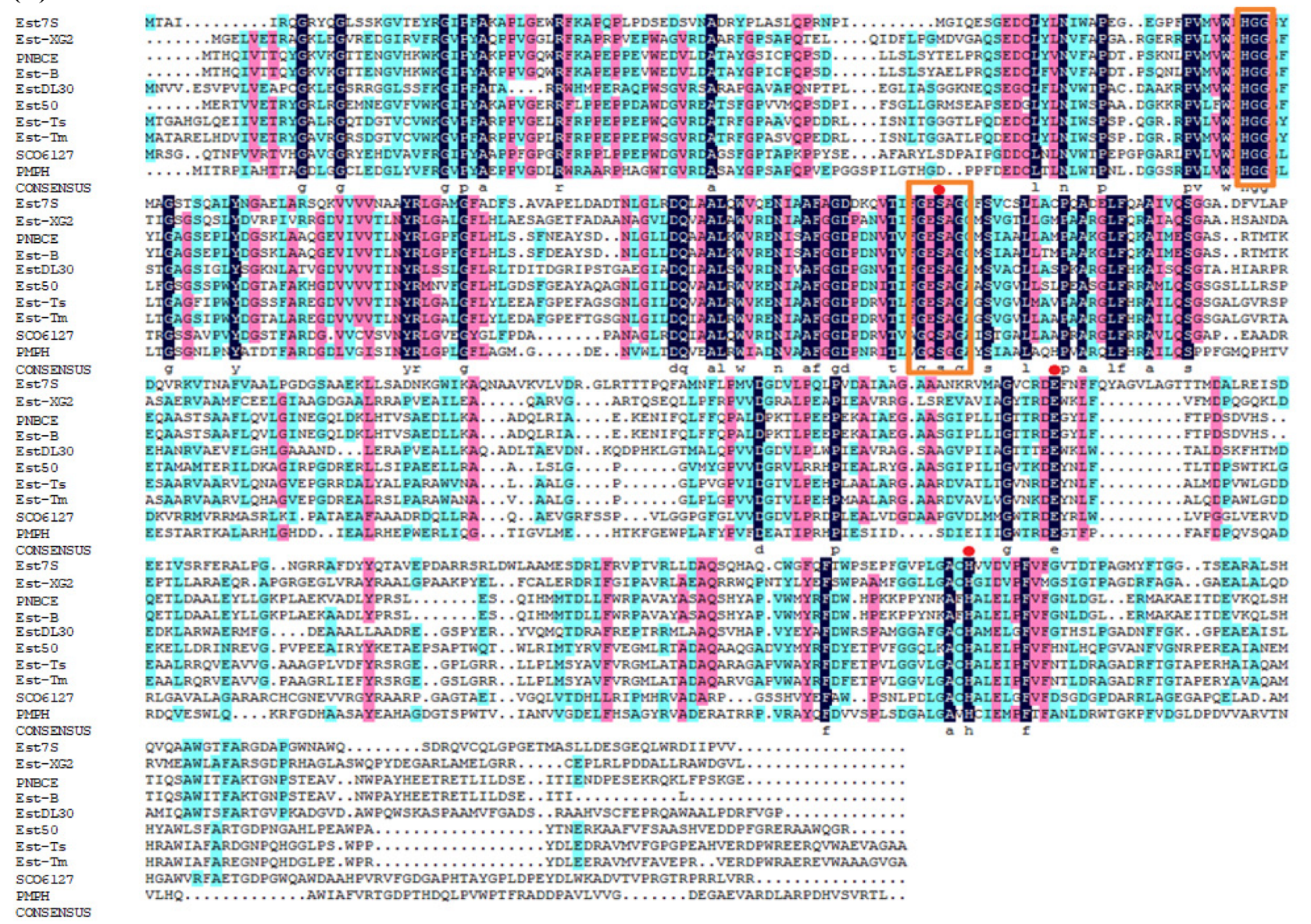

(B)

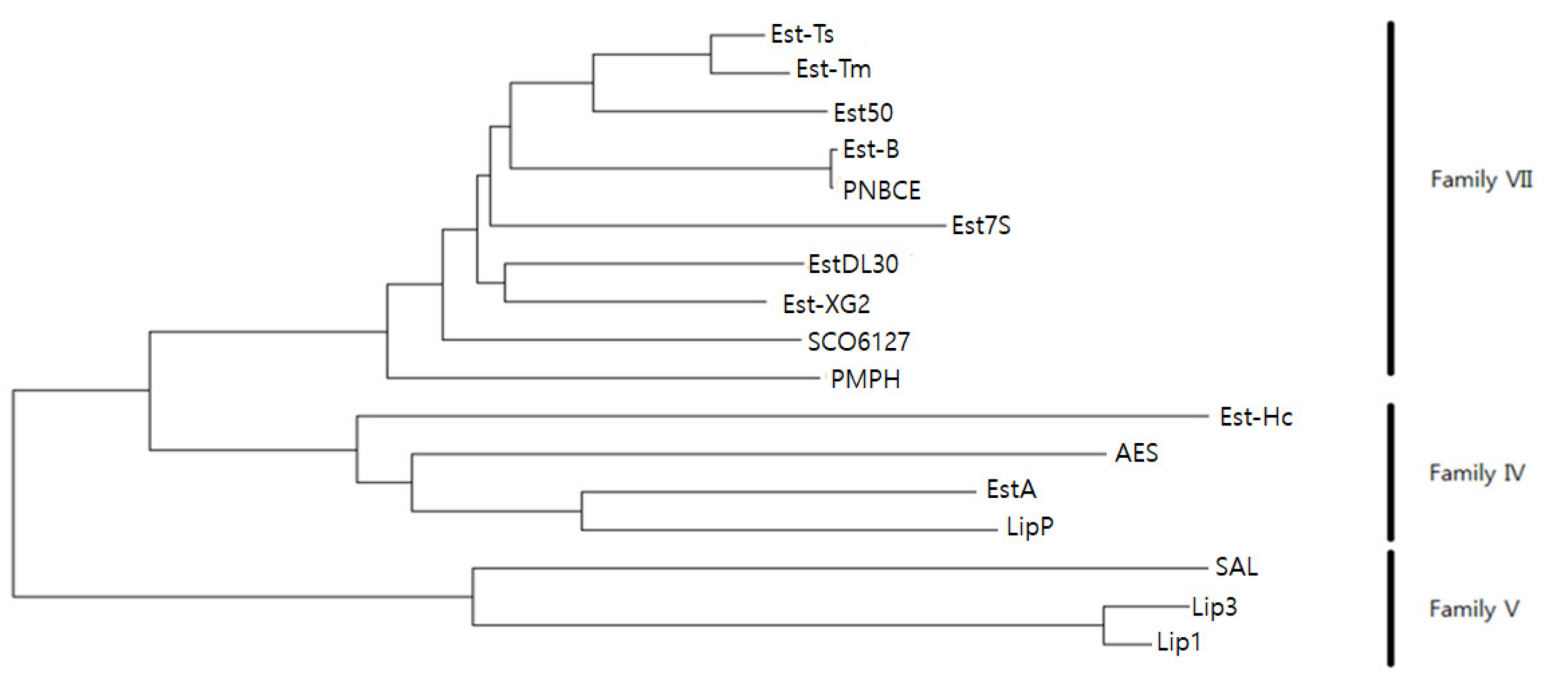

Fig. 2 Multiple alignment of the amino acid sequences (A), putative conserved domains (B), and phylogenetic tree of Est7S (C). The GxSxG and HGG motifs are boxed in orange. Red circles represent catalytic triad residues. In (A): Est-XG2, from Thermaerobacter marianensis DSM 12885 (AGS38342); PNBCE, Bacillus subtilis (P37967); Est-B, Bacillus sp. Za (AGY14298); EstDL30, an uncultured organism of soil (AEK77432); Est50, Geobacillus stearothermophilus (AAN81910); Est-Ts, Thermaerobacter subterraneus DSM 13965 (ZP_11320927); Est-Tm, Thermaerobacter marianensis (WP 013495056); SCO6127, Streptomyces coelicolor A3(2) (CAA22794); PMPH, Arthrobacter oxydans (Q01470). In (B): Est-Hc, from Hahella chejuensis KCTC2396 (ABC27396); AES, Escherichia coli str. K-12 substr. MG1655 (AAC73578); EstA, Archaeoglobus fulgidus DSM 4304 (AAB89533); LipP, Pseudomonas sp. strain B11-1 (AAC38151); SAL, Sulfolobus acidocaldarius DSM 639 (AAC67392); Lip3, Moraxella sp. TA144 (CAA37863); Lip1, Psychrobacter immobilis B10 (CAA47949) 
Table 1 Purification of an esterase Est7S from the clone SM7

\begin{tabular}{|c|c|c|c|c|c|c|}
\hline \multirow{2}{*}{ Procedure } & Volume & Total protein & Total activity & Specific activity & Purification & Yield \\
\hline & $(\mathrm{mL})$ & $(\mathrm{mg})$ & (U) & (U/mg) & (fold) & $(\%)$ \\
\hline Crude extract & 5.0 & 20.1 & 151.8 & 7.6 & 1.0 & 100 \\
\hline Sephacryl S-200 chromatography & 22.4 & 0.19 & 47.8 & 251.6 & 33.1 & 31.4 \\
\hline HiTrap Q chromatography & 1.0 & 0.012 & 4.4 & 366.7 & 48.3 & 2.9 \\
\hline
\end{tabular}

frame of $1,518 \mathrm{bp}$, which was expected to encode a protein of 505 amino acid residues with no signal peptide (Fig. 2A). The gene was matched to a putative $\alpha / \beta$ hydrolase superfamily and a carboxylesterase/lipase family, and was named est7S. Est7S was calculated to be 54,512 Da.

The amino acid sequence of Est7S showed the highest identity of $40 \%$ to an esterase Est-XG2 from an activated sludge metagenome [17], followed by $36 \%$ to a $p$-nitrobenzyl esterase of Bacillus subtilis [18] and an esterase EstDL30 from a soil metagenome [19], and 35\% to an esterase Est55 of Geobacillus stearothermophilus [20], by comparison enzymes with the reported properties. In comparison with the amino acid sequences from the genome sequences, Est7S showed 99\% identity to a carboxylesterase of Alcanivorax borkumensis SK2 (CAL16699), followed by $83 \%$ identity to that of Alcanivorax sp. DG881 (EDX91080), 76\% identity to that of Alcanivorax sp. MD8A (WP_102791219), and 72\% identity to that of A. nanhaiticus (WP_035231190). These sequences were annotated from genome sequences and their enzymatic properties have not yet been characterized. Analysis of the amino acid sequence and multiple alignment revealed that Est7S contained a catalytic triad, such as Ser183, Glu312, and His420; a GxSxG motif as GESAG in the $181^{\text {st }}-185^{\text {th }}$ residues; and an HGG motif at the N-terminus, found in most family IV, V, and VII. In the phylogenetic tree, Est7S was clustered with family VII esterases (Fig. 2B).

The highest similarity of Est7S was matched to the esterase of A. borkumensis. Though the production of hydrocarbon degrading enzymes (e.g. lipase and esterase) was recently studied from $A$. borkumensis, the enzymes were not cloned and characterized [21]. An esterase EstB was cloned and characterized from $A$. dieselolei, but the enzyme was different from Est7S, in that it was $45.1 \mathrm{kDa}$, cold-active, and $p$ NP-caproate (C6) preferred [22].

The $\alpha / \beta$-hydrolase superfamily, including esterases, contains Ser, Asp, and His, to form a catalytic triad [4]. Est7S contained Glu instead of Asp in the catalytic triad, like an acetylcholinesterase from Torpedo californica [23], a p-nitrobenzyl esterase of Bacillus subtilis [24], family VII Est-XG2 [17], and two family IV esterases (DMW18-543 and DMWf18-538) from a deep-sea sediment metagenome [25].

The typical pentamotif GxSxG has been reported to contain a serine residue that has a catalytic function found in most esterase families and in Est7S [26]. The pentamotif sequence was partially conserved in family VIII esterases, such as $\mathrm{GMS}_{372} \mathrm{RG}$ of Est $2 \mathrm{~K}$, $\mathrm{GMS}_{373} \mathrm{EG}$ of EstC, and $\mathrm{GLS}_{321} \mathrm{VG}$ of LipBL, but the Ser in the

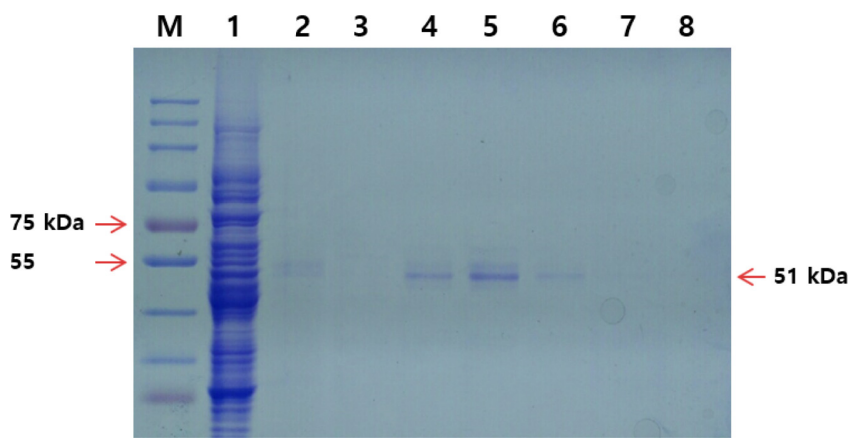

Fig. 3 SDS-PAGE of the Est7S during purification. M, molecular weight markers; lane 1, crude extract of the clone; lane 2, pooled from Sephacryl S-200 chromatography; lanes 3-8, fractions 68-78 at even numbers from HiTrap Q

motifs was not essential for the catalytic activity [10,27,28]. Instead, the family VIII enzymes have the SxxK motif, while family II (GDSL family) contain the GDSL motif.

\section{Purification of Est7S}

The crude extract of the clone SM7 showed $30.4 \mathrm{U} / \mathrm{mL}$ of esterase activity (Table 1). Est7S was purified from the crude extract using Sephacryl S-200 HR and HiTrap Q columns. Esterase activity was observed at late fractions from 96 to 120 in Sephacryl S-200 chromatography. In HiTrap Q chromatography, the activity was eluted from 69 to 77 after binding to the resin. Fraction 72 showed a thick protein band and fractions 71 and 72 were pooled. The recovery rate and purification fold were $2.9 \%$ and 48.3 -fold, respectively (Table 1). Purified Est7S showed a single band and had a molecular mass of $51.0 \mathrm{kDa}$, slightly smaller than the theoretical value, on an SDS-PAGE gel (Fig. 3). The smallest lipolytic enzymes belonged to family I.4, likely Lip7-3 (19 kDa) of marine bacterium Bacillus sp. W130-35 [11]. The large esterases were found in family I.3, likely Lip3K $(64 \mathrm{kDa})$ from the oilpolluted mud flat metagenome [9], or in most of family VII ( $\sim 55$ $\mathrm{kDa}$ [1]. Based on the results, Est7S was a large-sized enzyme with $55 \mathrm{kDa}$.

Specific activity of the purified enzyme was $366.7 \mathrm{U} / \mathrm{mg}$ protein. The specific activity of Est7S was in the upper range among family VII esterases such as Est-XG2 (17.71 U/mg protein) [17], EstDL30 (161 U/mg protein) [19], and an esterase NaM1 (488.9 $\mathrm{U} / \mathrm{mg}$ protein) from a desert metagenome [29]. Compared to others, Est7S was in the middle range; an esterase Est2K (family VIII, 17.1 U/mg protein) from a compost metagenome [10], Lip7- 

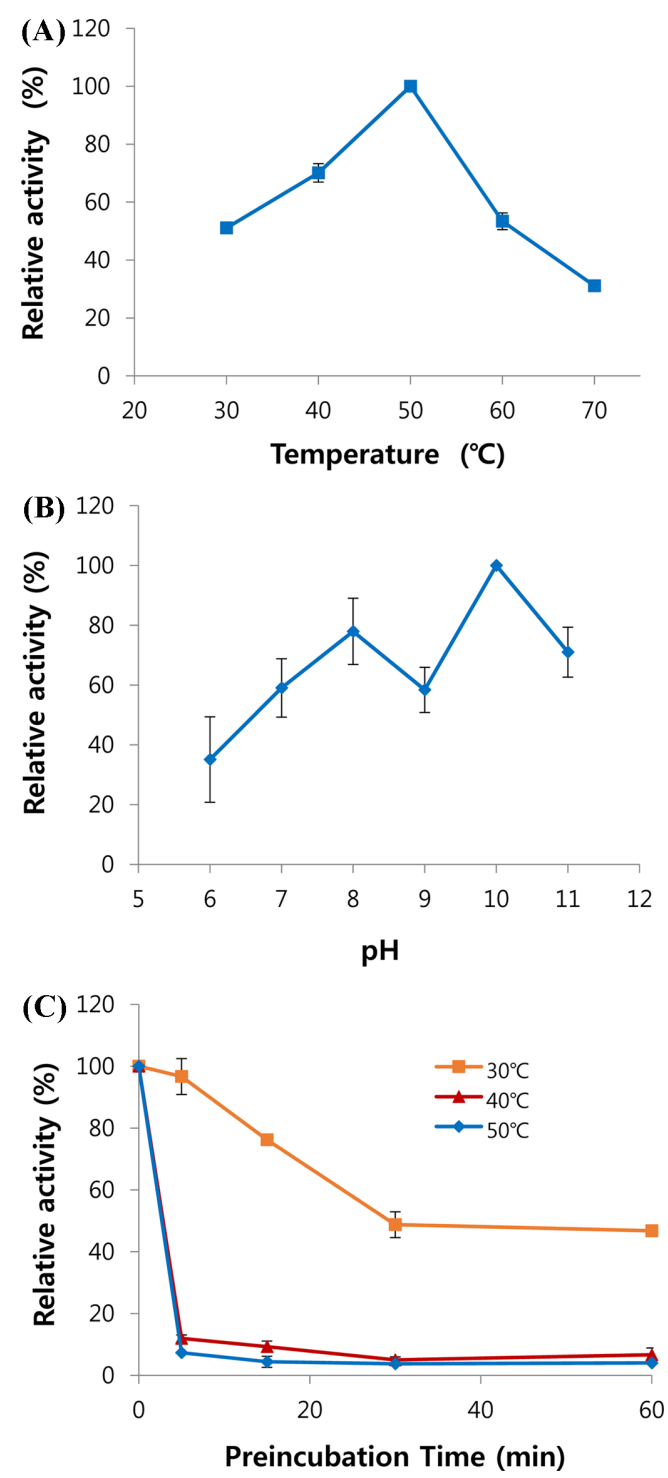

Fig. 4 Effect of temperature and $\mathrm{pH}$ on the enzyme activity of Est7S. (A), Optimum temperature; (B), Optimum $\mathrm{pH}$; (C) Thermostability. In the thermostability experiments, enzyme was pre-incubated without a substrate, and then the residual activity was measured under the standard assay condition

3 (family I.4, 81.3 U/mg protein) [11], EstN7 of B. cohnii strain N1 (family IV, $336.89 \mathrm{U} / \mathrm{mg}$ protein) [30], EstSP (family IV, $745.14 \mathrm{U} / \mathrm{mg}$ protein) from a soil metagenome [31], and Est7K (family VIII, 790.2 U/mg protein) from the compost metagenome [32].

\section{Properties of Est7S}

Est7S showed its maximal activity at $50^{\circ} \mathrm{C}$, and greatly decreased at 40 or $60^{\circ} \mathrm{C}$ (Fig. 4A). Est7S also showed its maximal activity at $\mathrm{pH} 10.0$ (Fig. 4B). At $\mathrm{pH} 9.0$, the activity was decreased to $58.4 \%$; however, it increased to $78.0 \%$ at $\mathrm{pH} 8.0$. The value of Est7S was higher than that of EstDL30 (pH 8.0) [19] and that of

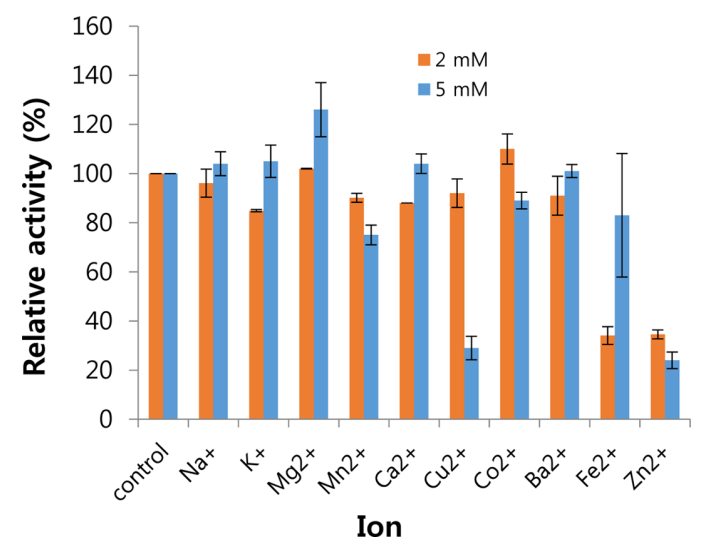

Fig. 5 Effect of metal ions on Est7S

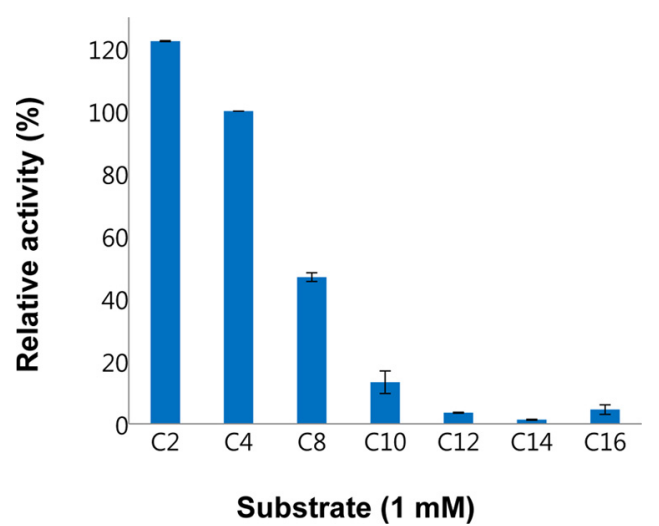

Fig. 6 Substrate specificity of Est7S for $p$ NP-esters. C2, $p$-nitrophenyl acetate; $\mathrm{C} 4, p$-nitrophenyl butyrate; $\mathrm{C} 8$, octanoate $p$-nitrophenyl octanoate; $\mathrm{C} 10, p$-nitrophenyl caprate; $\mathrm{C} 12, p$-nitrophenyl laurate; $\mathrm{C} 14$, $p$-nitrophenyl myristate; and $\mathrm{C} 16, p$-nitrophenyl palmitate

Est-XG2 (pH 8.5) [17]. The results suggested that Est7S had a broad alkaline range. In thermostability experiments, half-life of Est7S at $30^{\circ} \mathrm{C}$ was $29.7 \mathrm{~min}$, but those were less than $5 \mathrm{~min}$ at 40 or $50^{\circ} \mathrm{C}$ (Fig. $4 \mathrm{C}$ ). The optimum temperature $\left(50^{\circ} \mathrm{C}\right)$ of Est $7 \mathrm{~S}$ was in the middle range compared to those of other enzymes (20$\left.80^{\circ} \mathrm{C}\right)$.

Cations testing showed no significant effects on the enzyme activity at $2 \mathrm{mM}$, except that $\mathrm{Fe}^{2+}$ and $\mathrm{Zn}^{2+}$ inhibited to 34.1 and $34.5 \%$ of the activity (Fig. 5). At $5 \mathrm{mM}, \mathrm{Mg}^{2+}$ increased the activity to $126.0 \%$, but $\mathrm{Cu}^{2+}$ and $\mathrm{Zn}^{2+}$ inhibited to 29.0 and $24.0 \%$, respectively.

Purified Est7S hydrolyzed the ester bond of $\mathrm{C} 2$ with maximal activity, and then followed by $\mathrm{C} 4$ and $\mathrm{C} 8$ with 81.7 and $38.4 \%$, respectively (Fig. 6). Est7S preferred to short-chain fatty acid esters but hardly hydrolyzed the long-chain fatty acids, such as $\mathrm{C} 14$ and $\mathrm{C} 16$. The activity ratio for $\mathrm{C} 10$ to $\mathrm{C} 4$ was 0.13 , between Est7K (0.035) [32] and Est2K (0.4) [10]. Est7S preferred a shortchain fatty acid ( $\mathrm{C} 2$ or $\mathrm{C} 4)$ as the substrate, likely many esterases, such as EstSP (C2) [31], EstN7 (C2) [30], BlEst1 (C2) of $B$. licheniformis [33], EstSP2 (C2) of Sphingomonas glacialis [34], 

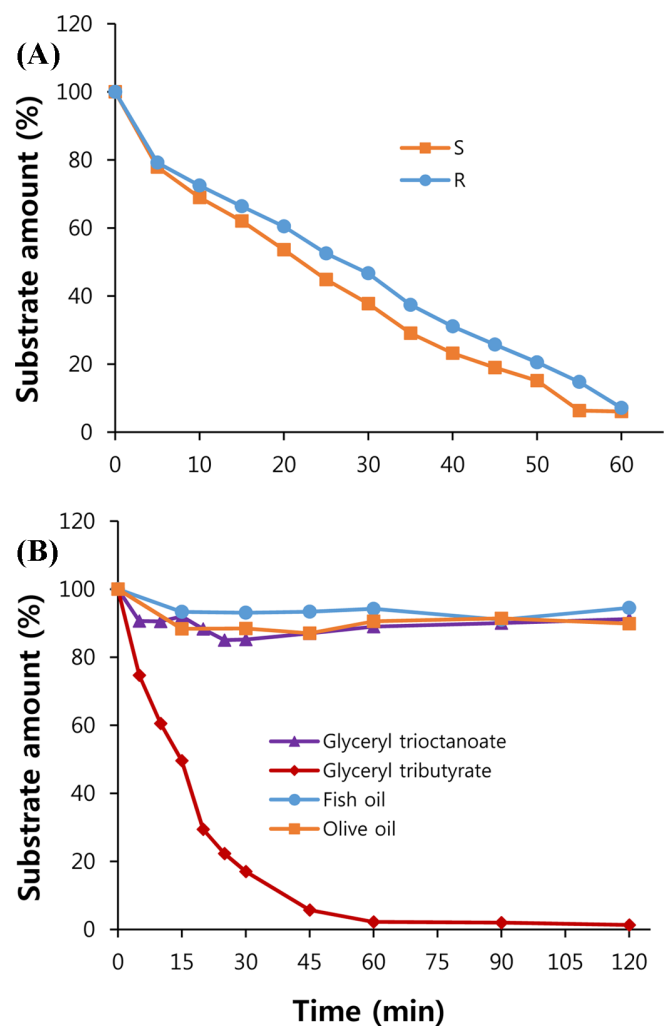

Fig. 7 Analysis of enantioselectivity and glyceryl substrate hydrolysis of Est7S. (A) Enantioselectivity analysis with $(R)$ - or $(S)$-methyl-3-hydroxy2-methylpropionate containing phenol red; (B) Hydrolysis of glyceryl esters and oils

and an esterase (C2) of Xanthomonas oryzae [35], but contrary to Lpc53E1 (C16) from the metagenome of the marine sponge Haliclona simulans [36] and KM12 lipase (C12) of B. licheniformis KM12 [37]. Based on the substrate preference, Est7S is a typical carboxylesterase rather than a lipase [4].

Est7S hydrolyzed an $R$-enantiomer, $(R)$-methyl-3-hydroxy-2methylpropionate, and its $S$-enantiomer. The half-lives of $R$ and $S$ isomer were 24.4 and $21.0 \mathrm{~min}$, respectively, under the experimental condition by measuring $\mathrm{A}_{560}$ (Fig. 7A). Est7S showed a lower enantioselectivity level for ( $S$ )-enantiomer of methyl-3-hydroxy-2methylpropionate than Est7K, which showed $S$-enantiomer preference [32]. Est7S efficiently hydrolyzed glyceryl tributyrate with a half-life of $15.0 \mathrm{~min}$, but hardly hydrolyzed glyceryl trioleate, fish oil, and olive oil (Fig. 7B). The results suggested that Est7S was specific to short glyceryl esters.

In this study, we cloned a new alkaline esterase Est7S from an enriched metagenomic library. Est7S showed a high specific activity and a specificity for short-chain fatty acid esters and activity including glyceryl tributyrate and the enantiomers. These properties of Est7S may provide potentials in biotechnological applications under alkaline condition and for short glyceryl esters.
Acknowledgments This paper was supported by the Sunchon National University Research Fund in 2018.

\section{References}

1. Ramnath L, Sithole B, Govinden R (2017) Classification of lipolytic enzymes and their biotechnological applications in the pulping industry. Can J Microbiol 63: 179-192

2. Sandoval G, Herrera-López EJ (2018) Lipase, phospholipase, and esterase biosensors. Methods Mol Biol 1835: 391-425

3. Gudiukaite R, Gricajeva A (2017) Microbial lipolytic fusion enzymes: current state and future perspectives. World J Microbiol Biotechnol 33: 216

4. Arpigny JL, Jaeger KE (1999) Bacterial lipolytic enzymes: classification and properties. Biochem J 343: 177-183

5. Charbonneau DM, Beauregard M (2013) Role of key salt bridges in thermostability of G. thermodenitrificans EstGtA2: distinctive patterns within the new bacterial lipolytic enzyme family XV. PLoS One 8: e76675

6. Schmeisser C, Steele H, Streit WR (2007) Metagenomics, biotechnology with non-culturable microbes. Appl Microbiol Biotechnol 75: 955-962

7. Lee DH, Moon SR, Park YH, Kim JH, Kim H, Parales RE, Kahng HY (2010) Pseudomonas taeanensis sp. nov., isolated from a crude oilcontaminated seashore. Int J Syst Evol Microbiol 60: 2719-2723

8. Lee DH, Moon SR, Park YH, Lee YS, Jung JS, Kim JH, Kim H, Kahng HY (2011) Gangjinia marincola gen. nov., sp. nov., a marine bacterium of the family Flavobacteriaceae. Int J Syst Evol Microbiol 61: 325-329

9. Kim HJ, Jeong YS, Jung WK, Kim SK, Lee HW, Kahng HY, Kim J, Kim H (2015) Characterization of novel family IV esterase and family I.3 lipase from an oil-polluted mud flat metagenome. Mol Biotechnol 57: 781-792

10. Kim YH, Kwon EJ, Kim SK, Jeong YS, Kim J, Yun HD, Kim H (2010) Molecular cloning and characterization of a novel family VIII alkaline esterase from a compost metagenomic library. Biochem Biophys Res Commun 393: 45-49

11. Kim HJ, Jung WK, Lee HW, Yoo W, Kim TD, Kim H (2015) Characterization of an alkaline family I.4 lipase from Bacillus sp. W13035 isolated from a tidal mud flat with broad substrate specificity. J Microbiol Biotechnol 25: 2024-2033

12. Petersen TN, Brunak S, von Heijne G, Nielsen H (2011) SignalP 4.0: discriminating signal peptides from transmembrane regions. Nat Methods 8: 785-786

13. Shin ES, Yang MJ, Jung KH, Kwon EJ, Jung JS, Park SK, Kim J, Yun $\mathrm{HD}$, Kim H (2002) Influence of the transposition of the thermostabilizing domain of Clostridium thermocellum xylanase (XynX) on xylan binding and thermostabilization. Appl Environ Microbiol 68: 3496-3501

14. Oh JM, Lee JP, Baek SC, Kim SG, Jo YD, Kim J, Kim H (2018) Characterization of two extracellular $\beta$-glucosidases produced from the cellulolytic fungus Aspergillus sp. YDJ216 and their potential applications for the hydrolysis of flavone glycosides. Int J Biol Macromol 111: 595603

15. Bradford MM (1976) A rapid and sensitive method for the quantitation of microgram quantities of protein utilizing the principle of protein-dye binding. Anal Biochem 72: 248-254

16. Laemmli UK (1970) Cleavage of structural proteins during the assembly of the head of bacteriophage T4. Nature 227: 680-685

17. Shao H, Xu L, Yan Y (2013) Isolation and characterization of a thermostable esterase from a metagenomic library. J Ind Microbiol Biotechnol 40: 1211-1222 
18. Zock J, Cantwell C, Swartling J, Hodges R, Pohl T, Sutton K, Rosteck P Jr, McGilvray D, Queener S (1994) The Bacillus subtilis pnbA gene encoding p-nitrobenzyl esterase: cloning, sequence and high-level expression in Escherichia coli. Gene 151: 37-43

19. Tao W, Lee MH, Wu J, Kim NH, Lee SW (2011) Isolation and characterization of a family VII esterase derived from alluvial soil metagenomic library. J Microbiol 49: 178-185

20. Ewis HE, Abdelal AT, Lu CD (2004) Molecular cloning and characterization of two thermostable carboxyl esterases from Geobacillus stearothermophilus. Gene 329: 187-195

21. Kadri T, Rouissi T, Magdouli S, Brar SK, Hegde K, Khiari Z, Daghrir R, Lauzon JM (2018) Production and characterization of novel hydrocarbon degrading enzymes from Alcanivorax borkumensis. Int J Biol Macromol 112: $230-240$

22. Zhang S, Wu G, Liu Z, Shao Z, Liu Z (2014) Characterization of EstB, a novel cold-active and organic solvent-tolerant esterase from marine microorganism Alcanivorax dieselolei B-5(T). Extremophiles 18: 251259

23. Sussman JL, Harel M, Frolow F, Oefner C, Goldman A, Toker L, Silman I (1991) Atomic structure of acetylcholinesterase from Torpedo californica: a prototypic acetylcholine-binding protein. Science 253 872-879

24. Spiller B, Gershenson A, Arnold FH, Stevens RC (1999) A structural view of evolutionary divergence. Proc Natl Acad Sci USA 96: 1230512310

25. Huo YY, Jian SL, Cheng H, Rong Z, Cui HL, Xu XW (2018) Two novel deep-sea sediment metagenome-derived esterases: residue 199 is the determinant of substrate specificity and preference. Microb Cell Fact $17: 16$

26. Bornscheuer UT (2002) Microbial carboxylesterase: classification, properties and application in biocatalysis. FEMS Microbiol Rev 26: 7381

27. Pérez D, Kovacic F, Wilhelm S, Jaeger KE, García MT, Ventosa A, Mellado E (2012) Identification of amino acids involved in the hydrolytic activity of lipase LipBL from Marinobacter lipolyticus. Microbiology 158: 2192-2203

28. Rashamuse K, Magomani V, Ronneburg T, Brady D (2009) A novel family VIII carboxylesterase derived from a leachate metagenome library exhibits promiscuous $\beta$-lactamase activity on nitrocefin. Appl Microbiol Biotechnol 83: 491-500

29. Adesioye FA, Makhalanyane TP, Vikram S, Sewell BT, Schubert WD, Cowan DA (2018) Structural characterization and directed evolution of a novel acetyl xylan esterase reveals thermostability determinants of the carbohydrate esterase 7 family. Appl Environ Microbiol 84: e02695-17

30. Noby N, Saeed H, Embaby AM, Pavlidis IV, Hussein A (2018) Cloning, expression and characterization of cold active esterase (EstN7) from Bacillus cohnii strain N1: A novel member of family IV. Int J Biol Macromol 120: 1247-1255

31. Jayanath G, Mohandas SP, Kachiprath B, Solomon S, Sajeevan TP, Bright Singh IS, Philip R (2018) A novel solvent tolerant esterase of GDSGG motif subfamily from solar saltern through metagenomic approach: Recombinant expression and characterization. Int $\mathrm{J}$ Biol Macromol 119: 393-401

32. Lee HW, Jung WK, Kim YH, Ryu BH, Kim TD, Kim J, Kim H (2016) Characterization of a novel alkaline family VIII esterase with Senantiomer preference from a compost metagenomic library. J Microbiol Biotechnol 26: 315-325

33. Nakamura AM, Kadowaki MAS, Godoy A, Nascimento AS, Polikarpov I (2018) Low-resolution envelope, biophysical analysis and biochemical characterization of a short-chain specific and halotolerant carboxylesterase from Bacillus licheniformis. Int J Biol Macromol 120: 1893-1905

34. Dachuri VK, Lee C, Jang SH (2018) Organic solvent-tolerant esterase from Sphingomonas glacialis based on amino acid composition analysis: cloning and characterization of EstSP2. J Microbiol Biotechnol 28: $1502-1510$

35. Kang HC, Kim JB, Lee HS, Cho KJ (2008) Cloning and characterization of an esterase from Xanthomonas oryzae pv. Oryzae. J Appl Biol Chem 51: $95-101$

36. Selvin J, Kennedy J, Lejon DP, Kiran GS, Dobson AD (2012) Isolation identification and biochemical characterization of a novel halo-tolerant lipase from the metagenome of the marine sponge Haliclona simulans. Microb Cell Fact 11: 72

37. Malekabadi S, Badoei-Dalfard A, Karami Z (2018) Biochemical characterization of a novel cold-active, halophilic and organic solventtolerant lipase from B. licheniformis KM12 with potential application for biodiesel production. Int J Biol Macromol 109: 389-398 